\title{
PEMBERDAYAAN MASYARAKAT \\ MELALUI PENGEMBANGAN POTENSI DESA WISATA KETINGAN KABUPATEN SLEMAN - DI YOGYAKARTA
}

\author{
Supartini \\ Dosen Akademi Maritim Yogyakarta (AMY)
}

\begin{abstract}
Empowerment is the study discussed in this research and it is related to the potential development of tourism village of Ketingan Tirtoadi Mlati Sleman Yogyakarta Special Region. The objective of this research is to answer the problems as follows: first is how the community empowerment in tourism village of Ketingan; second how is the public response to community empowerment and third is what are the supports and obstacles in the implementation of community empowerment.

This research is an empowering community research which is observing the implementation of empowerment by using library study and field studies as a means of data collection. The source of the data was obtained from the research site of Ketingan tourism village and taken from the competence informant as well as from the relevance and supporting government institution and private institutions. The data analysis was done by using qualitative analysis with descriptive approach which elaborates the data and the fact obtained from the research or the field of the research.

The finding of the research shows that the community empowerment in Ketingan tourism village has already ran smoothly although it has not reached the independence level. The potential development was conducted by the management which applies the tourism attraction, accommodation/home stay. The planning to form the tourism package which adopts the cluster management model needs to be considered seriously since it will give benefit and it can increase the involvement of UKM and the members of the community besides that it can be one of the tourism attractions. Most of the community members understand the meaning of empowerment so that the management finds it easily to implement and socialize the planned activities, although there are some constraints relating to the funding and the human resource.
\end{abstract}

\section{Keywords:}

Empowerment, Tourism Village, Independence

\section{INTISARI}

Pemberdayaan merupakan kajian yang dibahas dalam penelitian ini, terkait dengan pengembangan potensi Desa Wisata Ketingan Tirtoadi Mlati Sleman Daerah Istimewa Yogyakarta. Maksud dan tujuan dari penelitian ini adalah untuk menjawab permasalahan yang timbul yaitu pertama bagaimana pemberdayaan masyarakat di Desa Wisata Ketingan, kedua bagaimana upaya dan penguatan kelembagaan terhadap pemberdayaan masyarakat dan yang ketiga adalah apakah yang menjadi pendukung dan hambatan dalam pelaksanaan pemberdayaan masyarakat. 
Penelitian ini merupakan penelitian pemberdayaan masyarakat yang bersifat pengamatan pelaksanaan pemberdayaan dengan alat pengumpulan data berupa studi bahan pustaka dan studi lapangan. Adapun sumber data diperoleh di lokasi penelitian Desa Wisata Ketingan dengan mencari narasumber yang berkopenten dan dari sumber istansi pemerintah maupun swasta yang mendukung dan relevan. Analisa data dilakukan menggunakan analisis kualitatif dengan pendekatan deskriptif yang menguraikan data dan fakta yang didapat di lokasi penelitian.

Dari hasil penelitian menunjukkan bahwa pemberdayaan masyarakat di Desa Wisata Ketingan sudah berjalan lancar, walaupun belum sampai ketarap kemandirian. Pengembangan potensi dilakukan oleh pengelola diterapkan dalam bidang atraksi, akomodasi berupa homestay. Rencana pembentukan paket wisata model menejemen kluster perlu disikapi dengan serius, karena paket ini bermanfaat dan dapat meningkatkan, melibatkan UKM (Usaha Kecil Menengah) serta warga, dan menjadi dayatarik wisata. Sebagian besar warga mengetahui apa makna dari pemberdayaan, sehingga pengelola lebih mudah dalam melaksanakan dan mensosialisasikan kegiatan-kegiatan yang telah direncanakan, walaupun masih ada hambatan terkait dengan pendanaan dan Sumberdaya manusianya.

\author{
Kata Kunci: \\ Pemberdayaan, Desa Wisata, Kemandirian
}

\section{PENDAHULUAN}

Program pemberdayaan masyarakat secara umum bertujuan meningkatkan kesejahteraan, salah satunya melalui penguatan ekonomi lokal, pengembangan kultur kewirausahaan, penggalangan partisipasi masyarakat dan kegiatan usaha produktif lainnya yang berbasis sumberdaya lokal dan berkelanjutan. Disamping itu masyarakat kurang mampu diberikan kesempatan untuk mengelola kegiatan, sumberdaya dan dana sendiri. Merebaknya paradigma pemberdayaan sangat erat kaitannya dengan kebangkitan masyarakat sipil atau masyarakat madani yang berdaulat.

Pariwisata merupakan salah satu industri penting akhir-akhir ini, sektor pariwisata memberikan kontribusi sebesar 11\% bagi Gross Domestic Product (GDP) di dunia dengan memperkerjakan 200 juta orang sejak tahun 1950 hingga 1998. Tidak terkecuali bagi negara kita Indonesia, hadirnya pariwisata sebagai sebuah industri terbesar kedua (second biggest industry) di dunia setelah migas mampu menjadi primadona penghasil devisa negara (I Gede Pitana dan Putu G Gayatri; 2005; 1).

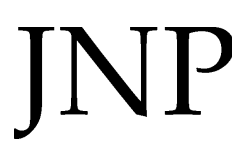

Menurut WTO (World Tourism Organization), sektor pariwisata mampu menyumbangkan pendapatan lebih dari US $\$ 3,5$ trilyun atau $6 \%$ dari pendapatan kotor dunia. Selain itu WTO juga memprediksikan bahwa pariwisata akan tumbuh dengan rata-rata pertumbuhan $4,2 \%$ pertahunnya selama 10 tahun dari tahun 2000-2010, dan salah satu kawasan yang akan mengalami tingkat pertumbuhan terbesar adalah negara-negara Asia termasuk Indonesia (Sedarmayanti; 2005; 13).

Perkembangan pariwisata dari tahun ke tahun begitu pesat yang ditandai dengan peningkatan jumlah kunjungan wisatawan baik domestik maupun mancanegara. Sudah sewajarnya apabila pemerintah mulai menggalakkan program pembangunan pariwisata diberbagai daerah, sekaligus menempatkan pariwisata sebagai pendekatan pembangunan alternatif (alternative development) dengan tujuan meningkatkan pertumbuhan ekonomi, dan meningkatkan kesejahteraan rakyat, mengurangi kemiskinan dan mengatasi pengangguran.

Melihat fenomena tersebut, pariwisata merupakan bagian integral dan tidak terpisahkan dengan pembangunan nasional 
(Maryani; 2006; 82), sekaligus sebagai sektor yang strategis yang dapat diandalkan dalam perolehan devisa negara, dan tidak akan pernah mengalamai pasang surut sepanjang masa.

Masyarakat sebagai salah satu stakeholders pembangunan pada prinsipnya memiliki wewenang dan tanggung-jawab besar terhadap pengelolaan pariwisata yang banyak memanfaatkan potensi sumberdaya. Masyarakat mempunyai kesempatan yang sama dan seluas-luasnya untuk berperan dalam pengelolaan lingkungan hidup dengan cara: a). meningkatkan kemandirian, keberdayaan masyarakat dan kemitraan; b). menumbuhkembang kan kemampuan dan kepeloporan masyarakat; c). menumbuhkan ketanggapsegeraan masyarakat untuk melakukan pengawasan sosial; d). memberikan saran pendapat; e). menyampaikan informasi dan atau menyampaikan laporan.

Menurut Wrihatnolo dan Dwidjowijoto (2007: 2-7) bahwa pemberdayaan adalah sebuah "proses menjadi", bukan sebuah "proses instan". Sebagai proses, pemberdayaan mempunyai tiga tahapan: penyadaran, pengkapasitasan, dan pendayaan. Secara sederhana ketiga tahapan tersebut dapat digambarkan sebagai berikut:

\section{Gambar 1.}

Tiga Tahapan Pemberdayaan

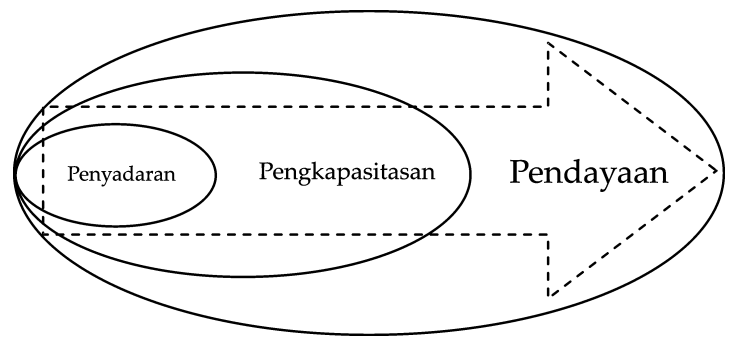

Sumber: Wrihatnolo dan Dwidjowijoto (2007: 3)

Sebagai dampak dari adanya pemberdayaan masyarakat, kemandirian merupakan kunci keberhasilan pemberdayaan masyarakat. Menurut Sastropoetro (1988), kemandirian adalah kemampuan dari suatu kelompok masyarakat dengan kesadaran dan inisiatif sendiri mengadakan ikhtiar kearah pemenuhan kebutuhan dan lain sebagainya.
Kemandirian tercermin dari perilaku, dapat diamati dari sikap seseorang karena kemandirian merupakan satu hal penting dalam proses pembentukan kepribadian masyarakat. Seseorang yang mandiri dapat menampilkan identitas dirinya dan mampu mengarahkan dirinya sendiri dalam menentukan sikap, mengambil keputusan serta dengan bijaksana dapat mengendalikan permasalahan yang dihadapi. Menurut Soetjiningsih dalam Rahman (2009, 51-52), kemandirian adalah merupakan perilaku yang ditandai oleh 4 (empat) aspek yaitu: Aktivitas sendiri, Kepercayaan diri, Inisiatif, dan Tanggung jawab.

Dalam upaya meningkatkan kualitas hidup masyarakat agar lebih baik, maka pariwisata sebagai passport pembangunan harus memberikan manfaat yang sebesarbesarnya bagi kesejahteraan masyarakat sekaligus memberdayakan dengan cara memperbesar multiplier effect dalam kesempatan kerja, peluang berusaha dan distribusi pendapatan (Damanik.J; 2005; 18).

Hal tersebut dapat terwujud jika makna pembangunan pariwisata pada tingkatan praktis diinterpretasi kan ulang, bukan hanya bersifat ekonomik semata (economic oriented) (Ahisma Putra, 2000; 1), sehingga pariwisata secara operasional betul-betul memberikan manfaat kepada masyarakat secara keseluruhan, baik pada aspek sosial maupun budaya. Pembangunan pariwiata yang memberdayakan masyarakat diharapkan mampu mendorong masyarakat berpartisipasi untuk mencapai tujuan kesejahteraan yang diharpkan bersama. Hal ini menjadi sangat penting, mengingat penafsiran atas berbagai kegiatan pariwisata didominasi oleh pandangan yang berorientasi pada pembangunan semata (development oriented), sehingga tidak jarang pembangunan pariwisata yang menitikberatkan pada kepentingan masyarakat (people oriented) terlewatkan dan nilainilai kemanusiaan (humanism) terabaikan.

Kabupaten Sleman memiliki potensi keragaman obyek wisata, spesifisitas obyek dengan karakter mantap dan unik seperti 
Taman Wisata Candi Prambanan yang memiliki kisah tentang budaya peninggalan sejarah, Taman Nasional Gunung Merapi. Kabupaten Sleman dikenal memiliki obyek dan daya tarik wisata (ODTW) yang beragam dan unik. Namun demikian sebagaimana produk yang mengikuti teori "life cycle", produk wisata yang tedapat di Kabupaten Sleman seperti Kaliurang, Kaliadem dan obyek wisata lainnya akan mencapai titik jenuh bagi wisatawan dengan ODTW yang ada, untukitu memerlukan kegiatan-kegiatan dan obyek wisata yang baru yang tentu saja ditunggu-tunggu oleh konsumen/wisatawan (Profil Desa wisata Kabupaten Sleman 2007).

Pemerintah Kabupaten Sleman akhirakhir ini banyak mengembangkan desa wisata (tourism village) sebagai daerah tujuan wisata (tourist desnitation) yang sampai saat ini telah tercatat memiliki sekita 38 (tigapuluh delapan) desa wisata (Dinas Budaya dan Pariwisata Kabupaten Sleman). Salah satu desa wisata yang termasuk daerah teritorial dan telah dikenal oleh banyak wisatawan baik wisatawan nusantara (domestic tourist) maupun wisatawan mancanegara (international tourist) adalah Desa Wisata Fauna burung Blekok dan Kuntul Dusun Ketingan. Desa wisata ini memiliki atraksi yang unik yaitu koloni dan habitat burung Blekok \& Kuntul yang tidak terdapat di obyek wisata lain, kegiatan seni budaya seperti Merti Bumi, Gejog Lesung, Jatilan, Daur Hidup, wiwit dan angler maupun kegiatan pertanian seperti membajak/nggaru, ngluku, menanam padi/ tandur, peternakan dan home industry, membuat jamu, membuat emping mlinjo yang dilakukan oleh masyarakat setempat.

\section{METODE PENELITIAN}

Penelitian ini merupakan penelitian kualitatif dengan motode deskriptif, yaitu prosedur penelitian yang menghasilkan data deskriptif berupa kata-kata tertulis atau lisan dan perilaku dari orang-orang yang diamati. Pendekatan ini diarahkan pada latar dan individu tersebut secara holistik (utuh), jadi tidak mengisolasikan individu atau organisasi ke dalam variabel atau hipotesis, tetapi perlu memandangnya sebagai bagian dari sesuatu keutuhan (Bogdan dan Taylor dalam Moleong, 2005: 4). Penelitian deskriptif bertujuan pertama untuk mengetahui perkembangan sarana fisik tertentu atau frekuensi terjadinya suatu aspek fenomena sosial tertentu; dan tujuan yang kedua adalah untuk mendeskripsikan secara terperinci fenomena sosial tertentu (Singarimbun dan Effendi, 1983: 4)

Untuk mendapatkan informasi yang sesuai dengan tujuan penelitian, maka peneliti mengambil data dari sumber data utama dalam penelitian kualitatif ialah katakata dan tindakan dari orang-orang yang diamati atau diwawancarai. Sumber data utama dicatat melalui catatan tertulis/catatan lapangan atau melalui perekaman video/audio tapes, pengambilan foto dan film. Sumber data lainnya dalam bentuk sumber tertulis yang dapat dibagi atas sumber buku dan majalah ilmiah, sumber dari arsip, dokumen pribadi dan dokumen resmi. Foto tentang orang dan latar penelitian baik foto dari orang lain maupun foto yang dihasilkan oleh peneliti sendiri; dan data statistik yang telah tersedia sebagai sumber data tambahan digunakan untuk melengkapi informasi sebagai pendukung penelitian ini (Moleong, 2005: 157-163)

Guna pengumpulan data dan memenuhi kebutuhan mendapatkan informasi yang lengkap, maka peneliti melakukan kegiatan terjun langsung ke lokasi penelitian. Pengamatan dilakukan berkaitan dengan aktivitas subyek penelitian yang sesuai dengan topik penelitian, sebagai contoh aktivitas keseharian masyarakat seperti bertani, berternak, membuat suatu produk, aktivitas gotong royong, cara melayani tamu dan mengelola akomodasi/ homestay, serta menyiapkan atraksi dan fasilitas wisatawan. Wawancara/interview dengan menunjuk beberapa informan yang dianggap mengetahui tentang data yang dibutuhkan dan analisis dokumen (Document analysis). 
Dalam penelitian ini, peneliti menggunakan analisa data secara induktif. Analisis ini berarti bahwa pengumpulan data buka dimaksudkan untuk membuktikan hipotesis akan tetapi lebih merupakan pembentukan abstraksi berdasarkan bagian-bagian yang telah dikumpulkan dan teknik analisis data adalah teknik analisis komponensial (componential analysis), untuk menganalisis unsurunsur yang memiliki hubungan-hubungan yang kontras satu sama lain dalam domaindomain yang telah ditentu kan untuk dianalisis secara lebih terperinci. Unsur-unsur yang kontras akan dipilah oleh peneliti dan selanjutnya akan dicari term-term yang dapat mewadahinya (Bungin, 2003: 95-96).

Untuk melengkapi data, diperlukan informan penelitian. Informan penelitian atau subjek penelitian terdiri dari pihak-pihak tertentu yang terlibat secara langsung maupun tidak langsung dalam proses pemberdayaan masyarakat meliputi pejabat struktural Dinas Pariwisata Kabupaten Sleman, Tenaga Pendamping Desa, Pengurus Koperasi, pengelola desa wisata. pengelola Unit-unit Usaha dan lembaga-lembaga sosial, keagamaan, tokoh masyarakat, pengurus kelompok masyarakat.

\section{HASIL PENELITIAN DAN PEMBAHASAN}

\section{Potensi Desa Wisata Kabupaten Sleman}

Dengan kemajuan jaman dan berkembangnya teknologi, maka kehidupan, peradapan, adat istiadat/kebiasaan dan siklus hidup manusia/ masyarakatpun akan berubah mengikuti perkembangan jaman. Upacara-upacara khas kebudayaan juga menggambarkan organisasi sosial. Pada saat ini ekowisata telah berkembang,wisata ini tidak sekedar untuk melakukan pengamatan burung, mengendarai kuda, penelusuran jejak di hutan belantara tetapi telah terkait dengan konsep pelestarian hutan dan penduduk lokal. Ekowisata merupakan suatu perpaduan dari berbagai minat yang tumbuh dari keprihatinan terhadap lingkungan, ekonomi dan sosial. Ekowisata tidak dapat dipisahkan dengan konservasi, oleh karena itu ekowisata disebut sebagai bentuk perjalanan wisata yang bertanggung jawab.

Wisata ekologis dapat dimungkinkan untuk mendapatkan manfaat sebesarbesarnya dari aspek ekologis, sosial budaya dan ekonomi bagi masyarakat pengelola dan pemerintah. Ekowisata merupakan bentuk wisata yang sangat erat dengan prinsip konservasi, bahkan dalam strategi pengbangan ekowisata juga menggunakan strategi konservasi. Dengan demikian ekowisata sangat tepat dan berdaya guna dalam mempertahankan keutuhan dan keaslian ekosistem di areal yang masih alami, bahkan dengan ekowisata pelestarian alam dapat ditingkatkan kualitasnya karena desakan dan tuntutan dari para ecotraveler

Dengan mempertimbangkan potensi dan peluang yang dimiliki, masalah yang dihadapi adalah pengembangan wilayah Kabupaten Sleman didasarkan pada pengembangan sektor ekonomi yang mempunyai keunggulan kompetitif. Dengan pengembangan sektor ekonomi maka akan tercapai pertumbuhan produktivitas wilayah yang tinggi sehingga Kabupaten Sleman mempunyai basis ekonomi yang tangguh. Sektor yang mempunyai keunggulan kompetitif adalah sektor yang mempunyai multiplier effect yang besar terhadap kegiatan perekonomian dan pengembangan kawasan sekitarnya, mempunyai permintaan pasar yang tinggi dan menarik minat swasta untuk menanamkan modalnya. Salah satu sektor yang mempunyai keunggulan kompetitif dalam rangka pengembangan ekonomi wilayah Kabupaten Sleman adalah sektor pariwisata.

Keuntungan ini menjadikan Sleman sebagai pusat aktivitas pariwisata, peluang ini ditangkap oleh seluruh civitas pariwitasa di Kabupaten Sleman dengan layanan wisata seperti pengembangan destinasi wisata, penyediaan sarana prasarana wisata, dan lainlain. Potensi budaya yang terdapat di Kabupaten Sleman terdiri dari peninggalan 
budaya dan upacara adat serta tradisi budaya yang turun menurun masyarakat Kabupaten Sleman. Sedangkan destinasi obyek wisata yang terdapat di Kabupaten Sleman diklasifikasikan menjadi wisata alam, candi, museum, pedesaan, pendidikan, belanja, kuliner, serta wisata alternatif.

Melihat potensi pariwisata yang telah berkembang baik obyek, infrastruktur, maupun pengusahanya, masih terdapat peluang investasi berdasar potensi alam yang ada yaitu keberadaan Gunung Merapi sebagai salah satu gunung teraktif di dunia dan dipadu dengan potensi Yogyakarta sebagai kota pendidikan. Obyek wisata yang memadukan potensi ter sebut antara lain yaitu museum Gunung Merapi dapat menjadi salah satu alternatif sarana rekreasi dengan pendekatan edu tourism. Di samping itu, untuk mengeksplorasi keindahan alam pedesaan, keunikan karakter masyarakatnya serta keragaman budaya, wisata pedesaan menjadi peluang yang cukup bagus untuk dikembangkan.

Pemerintah Daerah Kabupaten Sleman menyadari akan paradigma baru dalam pendekatan pembangunan pariwisata yang berbasis masyarakat (Community Based Development), sehingga pemerintah daerah mengajak secara aktif masyarakat untuk mengambil peran pada pembangunan pariwisata sesuai potensi yang ada, di masing-msing wilayah baik kecamatan maupun pedesaan. Hasilnya adalah telah terdapat sekitar 38 desa wisata yang tersebar di seluruh Kabupaten Sleman dengan kriteria tumbuh, berkembang dan mandiri, dengan potensi yang beragam. Dari 38 desa wisata dapat diklasifikasikan sebagai desa wisata budaya, desa wisata pertanian, desa wisata pendidikan, desa wisata fauna, desa wisata kerajinan dan desa wisata lereng Gunung Merapi.

Desa wisata merupakan suatu wilayah pedesaan yang memiliki potensi keunikan dan daya tarik yang khas, baik berupa karakter fisik maupun lingkungan alam pedesaan maupun kehidupan sosial budaya masyarakat. Desa wisata sebagai suatu bentuk integrasi antara atraksi, akomodasi dan fasilitas pendukung yang disajikan dalam suatu struktur kehidupan masyarakat yang menyatu dengan tatacara dan tradisi yang berlaku.

Peran pemerintah daerah Kabupaten Sleman terhadap perkembangan pariwisata, sangat strategis karena Pemda merupakan instansi yang berwenang mengambil kebijakan-kebijakan yang terkait dengan perkembangan daerah. Disamping dana dari APBD, salah satu upaya pemerintah untuk mempercepat penanggulangan kemiskinan melalui pengembangan desa wisata, sekarang diluncurkan Program Nasional Pemberdayaan Masyarakat (PNPM) Mandiri Pariwisata dari Kementrian Kebudayaan dan Pariwisata Pusat, yang mulai tahun 2008 - 2011 desadesa wisata yang mengajukan proposal dan disetujui dananya sudah turun. Dari desa wisata yang mengajukan proposal dana PNPM Mandiri Pariwisata, di tahun 2011, ada 11 desa wisata yang mendapatkan program PNPM senilai Rp. 65 juta (enampuluh lima juta rupiah).

Disampaikan oleh Haryanto seksi ODTW Dinas Budaya dan Pariwisata Kabupaten Sleman, pemberdayaan adalah dengan membangkitkan semangat masyarakat dan memfasilitasi, memotivasi sesuai dengan kapasitasnya maka masyarakat diberi kewenangan untuk mengelola dan merencanakan segala sesuatu yang diinginkan, agar lebih mampu, terampil sehingga bisa lebih maju dan mandiri.

Melalui Dinas Kebudayaan dan Pariwisata Kabupaten Sleman, yang tugas pokok dan fungsinya adalah $3 \mathrm{M}$, yaitu Memfasilitasi, Memotivasi dan Memasarkan obyek wisata yang berada di Kabupaten Sleman, maka selanjutnya beliau mengatakan dengan mengadakan even-even lomba dan diklat (Pendidikan dan Pelatihan) yang terkait dengan kepariwisataan diharapkan desa-desa wisata yang tumbuh dan berkembang akan bisa mandiri. 


\section{Proses Pemberdayaan Masyarakat Desa Wisata Ketingan.}

Berawal pada tahun 1997 saat peresmian pengaspalan jalan dusun dan pembangunan Gapura Dusun Ketingan yang bertuliskan: "Esthining Gapura Trus Manunggal oleh Raja Ngayojokarta Hadiningrat yaitu Ngarso Dalem Sri Sultan Hamengku Buwono X", yang didampingi oleh Permaisuri Kanjeng Ratu Hemas. Penggagas tulisan Esthining Gapura Trus Manunggal di gapura tersebut adalah sesepuh dan mantan Kepala Desa Tirtoadi yaitu Sumarsono (almarhum) yang mempunyai harapan dan tujuan agar warga masyarakat Ketingan khususnya selalu bersatu, Sakyeg Sakeko Proyo, Guyup Rukun (bersatu dan bersama-sama). Ketua Pengelola Desa Wisata Ketingan Bapak Haryono menuturkan, berawal pada tanggal 29 September 2002, KLH (Kementerian Lingkungan Hidup) bekerjasama dengan Puspar (Pusat Studi Pariwisata) Universitas Gajah Mada, memprakarsai beberapa sarasehan dan mengadakan Seminar Nasional dengan Thema Wisata Ramah Lingkungan. Bertempat di Dusun Ketingan dengan peserta ratusan orang yang pada waktu itu peserta menginap di Dusun Ketingan, dan tinggal di rumah-rumah warga selama 2 (dua) hari dengan makan dan tidur serta layanan dan fasilitas lain ala pedesaan.

Pada tahun 2005 digagaslah usaha untuk menjaga keberadaan burung blekok dan kuntul beserta habitatnya, maka dibentuklah organisasi dan disusun Pengurus Pengelola Desa Wisata Ketingan, dilengkapi dengan struktur organisasi dan personil pelaksannya. Akhirnya diputuskan Dusun Ketingan menjadi sebuah desa wisata dan konservasi burung blekok dan kuntul, yang menawarkan keindahan serta keasrian desa, serta tidak ketinggalan koloni burung blekok dan kuntul. Desa wisata Ketingan memiliki kelebihan nilai-nilai yang terkandung dalam perlindungan alam meliputi nilai keindahan, nilai pembelajaran, nilai ekonomi, nilai ilmiah dan nilai sosial budaya, konservasi, pendidikan dan rekreasi yang saling berkaitan. Nilai Konservasi/Pelestarian (ecology), adalah menjaga alam dan lingkungannya (flora, fauna dan habitatnya) agar tidak punah dalam jangka pendek dan jangka panjang/ lestari.

Prinsip dasar yang harus dilakukan dalam konservasi adalah: a). Perlindungan adalah menjaga tetap berlangsungnya proses ekologis yang tetap mendukung system kehidupan, melindungi keanekaragaman hayati, menjamin kelestarian, b). Pengawetan adalah menjaga agar tetap dapat dinikmati oleh generasi berikutnya, ini dilakukan untuk jangka pendek, c). Pemanfaatan sepanjang masa/lestari maksudnya bahwa di dalam memanfaatkan alam dan lingkungan unuk kepentingan kesejahteraan manusia tidak boleh merusak dan harus dipertahankan kelanjutannya.

Sebagai pedukuhan yang mengembangkan ekowisata perdesaan dengan potensi konservasi habitat burung blekok dan kuntul perlu disadari mengenai pentingnya pengelolaan potensi dan aset wisata yang ramah lingkungan. Menurut Chafid Fandeli (1995: 202), bahwa pemanfaatan sumberdaya alam untuk wisata yang langsung dapat dinikmati, tetapi ada pula yang harus dikelola terlebih dahulu disiapkan fasilitas dan utilitasnya. Pembangunan fasilitas dan utilitas ini dapat menimbulkan kerusakan terhadap lingkungan. Dampak negatif ini harus diantisipasi, diminimalisir agar dapat dicegah atau apabila telah muncul dampak negatif tersebut dapat ditanggulangi segera agar tidak merugikan baik bagi lingkungan maupun bagi masyarakat.

\section{Pembentukan Organisasi Desa Wisata Ketingan}

Seiring berjalannya waktu dan maraknya pendirian desa wisata di Kabupaten Sleman maka pada tahun 2002 melalui musyawarah Lembaga Pemberdayaan Masyarakat Desa (LPMD), maka dibentuklah Tim Pengelola Desa Wisata Ketingan, yang kepengurusannya disempurnakan setiap 3 (tiga) tahun. Tim ini bertanggungjawab kepada LPMD Dusun Ketingan. LPMD sebagai penanggung jawab mempunyai tugas 
sebagai lembaga yang bertanggung jawab untuk berkoordinasi dan memberdayakan seluruh unsur masyarakat dalam melaksanakan pembangunan di Dusun Ketingan. Tugas ketua LPMD adalah mengkoordinir semua kegiatan pemberdayaan, yang intinya adalah dari warga untuk warga, mulai dari perencanaan, pelaksanaan sampai dengan mengevaluasi kegiatan.

Selanjutnya pemberdayaan masyarakat menurut Haryono, Ketua Desa Wisata Ketingan adalah dengan melibatkan warga masyarakat untuk merencanakan, melaksanakan, memonitor/mengawasi, termasuk dalam pendanaan dan mengevaluasi program-program yang telah disepakati bersama yang ingin dicapai dengan kemampuan dan dukungan warga agar supaya hasilnya bisa maksimal.

Hal senada juga disampaikan oleh Supartinah Kepala Dusun Ketingan, bahwa pemberdayaan pada intinya adalah gotongroyong semua warga, saya tidak ada artinya apa-apa tanpa dukungan dan partisipasi serta kebersamaan warga masyarakat untuk menjalankan program-program yang telah direncanakan, karena saya hanya ngesuhi / mengkoordinir saja, sehingga kegiatan yang dilaksanakan dapat berjalan lancar dan berhasil seperti apa yang direncanakan dan diprogramkan sesuai kesepakatan.

Tim Pengelola Desa Wisata (TPDW) Ketingan dibentuk dengan maksud dan tujuan: 1). mengelola Desa Wisata Ketingan agar lebih tertib baik administrasi maupun kegiatannya secara berkesinambungan, 2). Untuk konservasi/ pelestarian burung blekok dan kuntul berikut pemeliharaan lingkungan dan habitatnaya agar tidak punah, 3). menampung permasalahan yang timbul dan berusaha mencari jalan keluarnya bagi kemajuan Desa Wisata Ketingan dan kesejahteraan masyarakat Keatingan, 4). Melakukan distribusi tugas dan tanggungjawab dengan seimbang dan merata.

Disamping organisasi desa wisata, LPMD dan PKK, untuk mendukung kegiatan pariwisata Dusun Ketingan telah tumbuh beberapa organisasi yang berbentuk kelom- pok seperti, kelompok kandang, KSP (Kelompok Simpan Pinjam) Rukun Abadi, Kelompok Bakul Kecil Rumaket, KUB/ Kelompok Usaha Bersama Amanah.

Bidang Ekonomi dan Pembangunan Kecamatan Mlati, menuturkan bahwa pemberdayaan masyarakat adalah melibatkan warga masyarakat dalam setiap kegiatan demi kesejahteraan warga dan meningkatkan kemampuan dan ketrampilan warga.

Kelompok di bawah ini mendapatkan dana yang berasal dari pemerintah daerah Kabupaten Sleman baik dari APBD I maupun APBD II pada tahun 2009 dengan rincian kucuran dana sebesar, lihat tabel di bawah ini.

Tabel 1.

Bantuan Dana untuk Kelompok Dusun Ketingan Tahun 2009

\begin{tabular}{|c|l|r|c|}
\hline No. & Nama Kelompok & Jml Dana (Rp) & Keterangan \\
\hline 1 & KSP Rukun Abadi & 5.000 .000 & APBD \\
\hline 2 & $\begin{array}{l}\text { Bakul Kecil } \\
\text { Rumaket }\end{array}$ & 5.000 .000 & APBD \\
\hline 3 & KUB Amanah & 5.000 .000 & APBD \\
\hline 4 & P3A/Irigasi & 35.000 .000 & APBD \\
\hline 5 & $\begin{array}{l}\text { Industri Rumah } \\
\text { Tangga }\end{array}$ & 20.000 .000 & $\begin{array}{l}\text { Penyuluh Pertanian } \\
\text { Yogyakarta. }\end{array}$ \\
\hline
\end{tabular}

Sumber: Bidang Ekbang Kecamatan Mlati.

Dana tersebut untuk kelompok usaha dipergunakan sebagai pendorong usaha agar dapat meningkat, sedangkan P3A sebesar Rp 35.000.000,00 untuk perbaikan irigasi dengan sistem padat karya, dan pengerjaannya dilakukan oleh warga Ketingan. Kemudian dari Sekolah Tinggi Penyuluh Pertanian Yogyakarta, juga pernah menyalurkan dana sebesar Rp 20.000.000,00 diperuntukan membantu industri rumah tangga yang dipergunakan untuk membeli alat-alat dan sebagian diberikan untuk modal usaha.

Dalam upaya pengembangan potensi dan penguatan kelembagaan maka dilakukan:

\section{Pembentukan Paket Wisata}

\section{Terpadu Model Menejemen Kluster}

Dalam pengelolaan pengembangan kawasan pariwisata di Desa Wisata Ketingan, disamping paket wisata yang sudah ada, pengembangan potensi atraksi wisata, 
meliputi: Konservasi burung blekok dan kuntul, pertanian, peternakan, seni dan budaya, Ketua Desa Wisata Ketingan Haryono menuturkan bahwa ada program pengembangan kawasan terpadu dan pembentukan paket wisata dengan model menejemen kluster. Pembuatan paket wisata terpadu diprakarsai oleh Progam Pascasarjana Magister Teknik Industri Universitas Islam Indonesia (UII). Kawasan yang dijadikan pilot project di Kecamatan Mlati meliputi Ketingan sebagai sentra Desa Wisata Fauna blekok dan kuntul, Desa Wisata Sendari sebagai sentra kerajinan bambu di desa Tirtoadi dan sentra Perikanan Mina Kepis di Burikan Sumberadi Mlati.

Jerri Irgo mengatakan dengan pembentukan kawasan paket wisata terpadu di Kecamatan Mlati, menurut beliau manajemen kluster ini sangat bermanfaat dan erat hubungannya dengan pemberdayaan masyarakat, karena melibatkan warga masyarakat 2 (dua) desa di Kecamatan Mlati, bahkan melibatkan komunitas UKM (Usaha Kecil Menengah) yang berada di dalam 3 (tiga) sentra tersebut. Selanjutnya beliau mengatakan bahwa yang dimaksud dengan pemberdayaan adalah: Menggerakkan, memotivasi komunitas masyarakat agar mempunyai nilai yang lebih tinggi dan mendapatkan manfaat yang lebih pula.

Sebetulnya program ini sudah dimulai dari akhir tahun 2010, tetapi karena terjadi keadaan darurat meletus dan eropsi serta lahar dingin Gunung Merapi, maka program ini sempat tertunda dan dilanjutkan di bulan Maret 2011, tetapi pertemuan-pertemuan tetap berjalan lancar. Bermula pada Rabu 30 Juni 2010, Dekan Fakultas Teknologi Industri Universitas Islam Indonesia (FTI UII), Gumbolo bersama Robbie Darsono, dan Tedy Alamsyah Dirut PT BPR Danagung Bakti Yogyakarta melakukan audiensi ke Bank Indonesia Yogyakarta. Rombongan diterima langsung oleh Sutikno Pemimpin Bank Indonesia Yogyakarta didampingi oleh Djoko Raharto selaku Associate Economist Bank Indonesia Yogyakarta, dan ibu Ratih Indrastuti serta Mas'ud Asj'ari selaku Konsultan PUMKM Kantor Bank Indonesia Yogyakarta.

Sedangkan manfaat dari paket terpadu tersebut Mina Kepis dapat mengembangkan perikanan yang nantinya tidak hanya melayani kuliner siap saji tetapi dapat membuat makanan lain sebagai oleh-oleh, misalnya dibuat abon ikan, kripik ikan, ikan goreng dan lain-lain. Sedangkan sisa-sisa kepala ikan atau duri-durinya dapat dimanfaatkan untuk suplay pakan blekok dan kuntul, yang suatu saat dapat dikembangbiakkan untuk keperluan Kuliner khas Ketingan. Dengan demikian membantu dan mengembangkan usaha warga ditiga sentra wisata tersebut. Ketua desa wisata, bahwa sudah banyak wisatawan dan calon wisatawan yang menanyakan apakah di Ketingan ada makanan khas blekok. Ini merupakan peluang bisnis yang perlu disikapi sehingga merupakan daya tarik tersendiri dan dapat meningkatkan pendapatan warga setempat.

Sebagai wisata tujuan minat khusus bagi wisatawan yang datang, baik domestik maupun asing diharapkan tidak sekedar menikmati atraksi wisata dan lalu pulang begitu saja. Pengunjung menjadi krasan dan bersedia menginap di rumah-rumah penduduk yang sebelumnya telah dibuat sebagaimana kamar hotel minimal kelas Melati. Pemilik homestay telah melengkapi kamar penginapan secara memadai, didukung kebersihan dan keamanan. Demikian juga harus bersedia melayani tamu yang menginap dengan ramah dan mengesankan, serta menyediakan menu makanan yang baik dan sehat, sehingga citra penginapan/homestay walaupun sederhana tetapi wisatawan dapat merasakan kenyamanan dan kepuasan tersendiri.

Pemilik homestay di Dusun Ketingan berjumlah 47 orang dengan jumlah kamar 107 unit, dapat menampung 234 orang pengunjung. Biasanya rombongan wisatawan dari luar kota (Jakarta dan Surabaya) terutama dari SMA atau perguruan tinggi bersedia menginap. Siang hari wisatawan 
menuju obyek-obyek wisata seperti Kraton, Parangtritis, Prambanan atau Borobudur, kemudian sore, malam atau paginya melihat dari dekat atraksi burung kuntul dan konservasi yang telah dilakukan. Selanjutnya dengan dosen atau guru pembimbingnya diskusi bersama di joglo-joglo yang tersedia secara berkelompok.

Kunjungan wisatawan di Desa Wisata Ketingan mencapai ribuan orang kecuali di tahun 2009 turun dratis hanya 250 orang. Data tentang adanya kunjungan wisatawan baik domestik maupun mancanegara Desa Wisata Ketingan cukup baik. Meskipun tidak naik secara tajam tetapi perkembangan wisatawan yang datang cukup memberikan harapan, sepanjang usaha perbaikan internal dan usaha promosi ditingkatkan secara berkelanjutan. Sebagaimana data kunjungan wisatawan dalam 6 (enam) tahun terakhir dari tahun 2005 s.d tahun 2010 dapat dilihat dalam tabel 2 di bawah ini.

Tabel 2.

Data Kunjungan Wisatawan Desa Wisata Ketingan

\begin{tabular}{|c|c|c|c|}
\hline \multirow{2}{*}{ Tahun } & \multicolumn{2}{|c|}{ Wisatawan } & \multirow{2}{*}{ Jumlah } \\
\cline { 2 - 3 } & Domestik & Asing & \\
\hline 2005 & 950 & 2 & 952 \\
\hline 2006 & 592 & - & 592 \\
\hline 2007 & 671 & 11 & 682 \\
\hline 2008 & 1.970 & 7 & 1977 \\
\hline 2009 & 248 & 2 & 250 \\
\hline 2010 & 1253 & 45 & 1298 \\
\hline
\end{tabular}

Sumber: Sekretariat Dusun Ketingan Tahun 2011

Dari data kunjungan yang tercatat di sekretariat Desa Wisata Ketingan tidak semua wisatawan menginap. Masih banyak pengunjung yang hanya numpang lewat, melihatlihat keadaan lingkungan dan tidak mencatatkan diri ke sekretariat.

\section{Peningkatan SDM Bidang \\ Konservasi Pariwisata dan Kantib.}

Komponen dan aset yang dimiliki desa yang sangat pokok adalah sumberdaya manusia (SDM) yang cerdas dan terampil, agar supaya kegiatan konservasi dan pengem- bangan desa wisata dapat dikelola dengan baik sehingga dapat mencapai tujuan. Untuk itu ada 2 (dua) program kegiatan yang berhubungan dengan peningkatan SDM yang dilaksanakan, yaitu pertama peningkatan SDM bidang konservasi dan kedua peningkatan SDM Bidang Pariwisata. Meskipun demikian pelaksanaan pendidikan dan pelatihan tersebut keduanya dapat berdiri sendiri atau secara bersama dalam satu kegiatan dengan memberikan pendidikan dan pelatihan yang diselenggarakan oleh instansi yang berwenang.

\section{Prestasi dan Penghargaan Desa Wisata Ketingan}

Berkat kebersamaan, usaha keras, kegigihan dan jerih payah warga masyarakat, dusun Ketingan yang telah melakukan pengembangan dan perbaikan baik fisik maupun atraksi yang disuguhkan, semenjak kedatangan burung blekok dan kuntul tersebut, telah mendapatkan penghargaan, terutama bidang konservasi dan lingkungan hidup baik dari instansi pusat maupun daerah.

Adapun prestasi penghargaan yang pernah diterima warga Ketingan antara lain: (1) Penghargaan tertinggi dari Direktur Konservasi KeanekaragamanHayati Departemen Kehutanan RI Nomor 79/IV/KKH-6/ 2002 kepada warga masyarakat Dusun Ketingan atas partisipasinya dalam melestarikan habitat burung blekok dan kuntul sehingga dapat hidup berdampingan di lingkungan desanya.(2)Penghargaan Pemerintah Kabupaten Sleman dalam rangka hari lingkungan hidup tahun 2003, diberikan kepada Kelompok Lingkunan Dusun Ketingan, Kategori Penyelamat Lingkungan, dalam Kegiatan Penyelamatan Burung Kuntul di Desanya. (3). Penghargaan dan Trophy dari Kementerian Budaya dan Pariwisata Jakarta Tahun 2011 dalam Festival desa Wisata se kabupaten Sleman, apresiasi satu-satunya desa wisata fauna dan konservasi burung Blekok dan Kuntul beserta habitatnya. (4). Juara I Lomba Desa se kabupaten Sleman 
dalam rangka Hari Jadi Kabupaten Sleman Tahun 2011, mewakili desa Tirtoadi Mlati Sleman dan maju ke tingkat Propinsi. (5). Juara I Kategori Sapi Indukan diberikan kepada Kelompok Kandang Ngudi Lestari dalam HUT RI Tahun 2010 se Kecamatan Mlati. (5). Juara II Kategori Kebersihan Lingkungan Kandang diberikan kepada Kelompok Kandang Ngudi Lestari dalam HUT RI Tahun 2010 se Kecamatan Mlati.

\section{Potensi Wisata, Atraksi dan Daya Tarik Desa Wisata Ketingan}

Keanekaragaman hayati yang ada di kawasan hutan lindung dan kawasan konservasi lainnya perlu dijaga dengan upayaupaya perlindungan agar kelestariannya terjamin dan tidak mengalami kerusakan dan kepunahan. Sebagaimana tersebut dalam ketentuan UU Nomor 41 Tahun 1999 Tentang Kehutanan yaitu, bahwa hutan memiliki fungsi hutan lindung, fungsi hutan produksi dan fungsi hutan konservasi. Ketingan merupakan salah satu tempat konservasi burung kuntul yang dilindungi menurut undang-undang. Konservasi sendiri mempunyai azas pelestarian dan azas manfaat, sehingga bagaimana kita bisa melestarikan burung blekok dan kuntul tetapi juga mendapatkan manfaat ekonomi dari konservasi tersebut.

Balai KSDA (Konservasi Sumber Daya Alam) Yogyakarta sebagai unit pelayanan teknis di bawah Departemen Kehutanan dalam melaksanakan tugas pokok dan fungsinya, mempertegas peranan sebagai lembaga pemerintah untuk melestarikan fungsi lingkungan hidup. Sebagai instansi pemerintah tidak terlepas dari tugas-tugas umum pemerintah seperti perlindungan dan pelayanan. Dengan kedudukan tersebut Balai KSDA Yogyakarta dalam melaksanakan tugas pokok secara struktural bertanggung jawab kepada Direktoral Jendral Perlindungan Hutan dan Konservasi Alam Departemen Kehutanan RI.

Balai KSDA Yogyakarta telah melakukan inventarisasi potensi kawasan, sumberdaya alam hayati dan ekosistemnya yang terdapat dalam kawasan. Pembinaan dan penyuluhan kepada masyarakat terutama yang terdapat disekitarnya adalah sangat urgen dalam rangka pengamanan dan pelestarian keanekaragaman hayati. Peranan penting yang selama ini belum disadari oleh kebanyakan masyarakat, mengingat pemanfaatan tumbuhan dan satwa liar masih didasarkan pada pertimbangan dan penghitungan sosialekonomi. Pengambilan tumbuhan atau penangkapan satwa satwa di alam baik di dalam maupun di luar kawasan merupakan bukti nyata pengabaian aspek pelestarian. Sebagai akibatnya pemanfaatan tumbuhan dan satwa liar tersebut telah dan akan menimbulkan kekhawatiran punahnya berbagai spesies, dan satwa serta habitatnya.

Mengutip wawancara Budi Handojo $(2008,87)$ dengan staf kerjasama dan humas Balai KSDA Yogyakarta ibu Ilmi Kurniawati, S.Si, beliau mengatakan bahwa dengan mengacu ketentuan PP No. 7 Tahun 1999, Tentang Keberadaan Burung Blekok dan Kuntul, yang memiliki habitat beserta ekosistemnya di desa wisata Ketingan adalah pertama untuk burung blekok tergolong satwa yang tidak dilindungi, sehingga masyarakat luas boleh dengan bebas memanfaatkan untuk hobby atau lainnya. Kedua untuk burung kuntul tergolong satwa yang dilindungi, maka masyarakat dilarang memanfaatkan untuk hobby atau kesenangan yang lain. Pemanfaatan dan pemeliharaan burung kuntul berlaku sesuai peraturan perundang-undangan yang berlaku, bahkan apabila ada yang melanggar dapat dikenai sanksi pidana.

Dusun Ketingan telah ditetapkan menjadi desa wisata fauna Sejak tahun 2002 di bawah pembinaan Balai KSDA Yogyakarta dengan Dinas Kebudayaan dan Pariwisata Kabupaten Sleman yang bertindak sebagai motivator, fasilitator dan pemasaran. Pengembangan pariwisata yang bertumpu atas pengelolaan konservasi kawasan ini diharapkan memiliki manfaat ganda, sebagai kegiatan ekowisata (ecotourism), sekaligus upaya melindungi ekologi. Dari sisi sosial 
ekonomi warga memperoleh pendapatan dari kunjungan wisatawan dengan daya tarik atraksi habitat burung blekok dan kuntul, sedangkan sebagai kawasan esensial tetap terjaga kelestarian lingkungannya. Kebijakan yang dilaksanakan oleh Balai KSDA Yogyakarta terhadap kawasan esensial di dusun Ketingan adalah yang terpenting dilindunginya ekologi, yaitu dengan melestarikan burung blekok dan kuntul beserta habitatnya sehingga sebagai kawasan penyangga ekosistem kehidupan dapat dipertahankan eksistensinya. Perlindungan ini dilakukan baik terhadap burung blekok dan kuntul beserta habitatnya, karena kebiasaan jenis burung air ini sering hidup berdampingan dalam suatu habitat tertentu. Ibaratnya setiap ada koloni burung kuntul bersarang mesti diikuti keberadaan burung blekok di sekitarnya meskipun dalam jumlah yang kecil.

Dari penjelasan di atas bahwa burung blekok khususnya yang tidak dilindungi dan boleh dimanfaatkan untuk kesenangan dan hobi, maka burung blekok dapat dikembangkan sebagai potensi wisata bidang kuliner dengan cara mengolah blekok dan telornya menjadi makanan/lauk khas Ketingan, sehingga pengunjung di samping dapat menikmati pemandangan burung blekok dan kuntul sebagai atraksi wisata, tetapi bisa juga menikmati lezatnya masakan blekok sebagai sajian kuliner khas Ketingan. Dengan cara bekerjasama dengan pihak PHRI, yang memiliki tenaga-tenaga ahli memasak yang handal di bidang kuliner.

Warga masyarakat Ketingan mayoritas sekitar 749 orang $(94,81 \%)$ adalah muslim beragama Islam, sedangkan sekitar 41 orang $(5,19 \%)$ beragama non muslim khususnya beragama Katholik. Tetapi mereka hidup rukun dan saling berdampingan, toleransi antar umat beragama sangat baik, dibuktikan apabila ada acara-acara keagamaan kedua belah pihak saling mendukung dan saling membantu. Tempat ibadah warga Ketingan yang beragam Islam, bertempat di Masjid AnNur yang didirikan di selatan dusun dan mampu menampung jama'ah sekitar 200 orang. Sedangkan pemeluk agama non muslim mereka beribadah bergambung dengan jema" ah lain di tempat yang telah ditentukan. Untuk mempelajari dan mendalami Al Qur"an beserta kajian tafsirnya, di Dusun Ketingan juga terdapat Yayasan Majlis Tafsir AlQur"an (MTA) yang tempatnya didirikan disebelah barat dusun Ketingan dengan model salah satu rumah Joglo yang dimiliki oleh dusun Ketingan, rumah Joglo yang kelihatan indah dan menarik karena terawat dengan baik.

Kesenian merupakan kegiatan yang turun temurun dilakukan oleh warga dusun Ketingan yang diwariskan dari orang tua kepada putra putrinya. Kesenian tersebut antara lain seperti kesenian krawitan/gamelan untuk mengiringi tembang mocopatan, pangkur atau campur sari. Kesenian jatilan yang dikelola muda-mudi dan dibina dalam kelompok "Turonggo Krido",

Pada intinya kegiatan kesenian tersebut, sebagaimana dituturkan oleh Kepala Dusun, Ibu Supartinah bahwa kegiatan kesenian merupakan warisan budaya leluhur dan orang tua kami, dan kami sebagai anak-anak dan generasi penerusnya mempunyai kewajiban untuk menghidupkan, melestarikan atau istilahnya nguri-uri dan nglestantunaken. Pokoknya jangan sampai hilang atau punah oleh karena anak-anak muda jaman sekarang jarang yang mau peduli dan mau bersama orang-orang tua melestarikannya.

Kesenian cukup tua dan jarang tampil akan tetapi di Dusun Ketingan masih hidup, yaitu kesenian "gejok lesung", tetabuhan yang menggunakan lesung untuk nutu/ menguliti padi jaman dulu pada waktu mulai acara hajatan. Kesenian ini dilakukan oleh kelompok ibu-ibu PKK Ketingan dan biasanya sambil mengiringi lagu-lagu dandang gulo sampai campur sari. Kesenian ini dipentaskan pada saat menyambut tamu pada acara-acara tertentu maupun kedatangan wisatawan.

Budaya Merti Bumi juga merupakan tradisi yang merupakan warisan leluhur yang dilaksanakan setiap tahun pada bulan ruwah/ 
bulan Islam bersama-sama acara nyadran, yang merupakan ungkapan rasa syukur warga Ketingan atas hasil panen yang melimpah. Pagi itu di tempat tersebut memang sedang digelar acara Merti Dusun Ketingan, para bregodo telah siap membawa jodang yang berisikan gunungan untuk dikirab. Ada tiga buah gunungan yaitu gunungan berupa nasi tumpeng dengan tinggi sekitar 2 meter dihiasi dengan sayur mayur, kemudian ada gunungan hasil bumi yang berisikan berbagai macam hasil pertanian (polo kependem) dan perkebunan, dan jodang yang berisikan hasil pertanian berupa buah-buahan (polo gumantung) yang ditata rapi dan dihias.

Kegiatan ini dipusatkan di rumah ibu Supartinah, Kepala Dusun Ketingan. Pada tahun 2010, sebelum diberangkatkan kirab Merti Dusun dibuka oleh GKR Pembayun, putri sulung Sri Sultan HB X. Beliau mengatakan, upacara adat ini harus terus dilestarikan, karena memang milik masyarakat. Dan kegiatan ini menurut beliau, bisa dijadikan agenda wisata tahunan oleh Dinas Kebudayaan dan Pariwisata Sleman. Pemerintah bisa saja mengajak wisatawan karena Merti Dusun ini memiliki daya tarik yang luar biasa. Beliau mencontohkan Bali yang sudah menjadikan Merti Dusun sebagai agenda tahunan masyarakat. Dimana wisatawan diajak langsung dalam setiap proses, dan rangkaian acara yang berlangsung. "Saya harapkan ini bisa menjadi agenda wisata bagi dusun setempat sehingga menarik wisatawan untuk hadir dan menikmati langsung," kata GKR Pembayun.

Dalam wawancara kami dengan beberapa pinisepuh (orangtua yang umurnya sekitar 60 tahun ke atas) yang tidak mau disebut namanya, dengan logat jawa beliau ngendiko/ bicara: niki tho bu pemberdayaan, gotong-royong sae bantu tenogo, beo, pikiran kagem nyengkuyung kegiatan mertibumi, wiwit saking ngrencanaaken, dumugi rampong pagelaran wayang kulit sedalu natas. Namung kemawon kulo ragi prihatos, akhir-akhir meniko saksampunipun pemilihan bu dukuh lan pemilihan bupati kawontenan kerukunan warga radi keganggu kalian kagolis-kagolis ingkang mboten trimah menawi jagonipun kawon, saenggo mboten ndukung kegiatan-kegiatan dusun lan kegiatan masyarakat. Maksudnya dalam bahasa Indonesia (Ini bu pemberdayaan, semua warga bergotong-royong baik itu membantu tenaga, biaya maupun pikiran, untuk mendukung kegiatan merti bumi, mulai dari merencanakan sampai selesai pagelaran wayang kulit semalam suntuk. Namun saya merasa prihatin akhir-akhir ini sestelah ada pemilihan kepala dusun dan bupati, keadaan kerukunan warga agak terganggu dengan kagolis-kagolis yang tidak mau menerima kekalahan jagonya, sehingga tidak mendukung kegiatan-kegiatan dusun dan kegiatan masyarakat.

Dalam kirab tersebut melibatkan ratusan orang yang berjalan kaki, dari mulai anakanak yang berpakaian ala Blekok dan Kuntul ciri khas Ketingan, anak-anak muda dengan pakaian adat jawa dan group drumband yang berpakaian aneka warna, orang tua berpakaian jawa, petani, pakaian ulama dan sebagainya dengan memikul uborampe hasil panen yang diwujudkan dalam satu perangkat tumpeng/nasi dibentuk kerucut yang besar dan dihias dengan sayur mayur, seperangkat polo kependem (hasil bumi dari dalam tanah) sepeti ubi, tales, ketela pohon dan lain-lain, lalu seperangkat hasil polo gumantung (hasil bumi yang tergantung), seperti buah-buahan. Dibelakangnya dikawal oleh satu regu berpakaian prajurit dan bersenjata tumbak dan satu rombongan penunggang kuda berpakaian jawa lurik.

Semua itu dilakukan dari ekspresi rasa syukur warga masyarakat Ketingan atas rahmat dan hidayahNya, karena hasil panen tahun ini baik. Tidak hanya sampai disitu sukaria warga, walaupun rasa cape, kedinginan mereka abaikan dan melanjutkan acara, yaitu setelah kirab dilaksanakan malam harinya digelar/disuguhkan pagelaran wayang kulit semalam suntuk dengan dalang Ki Bambang Srilungit dan bintang tamu Paidi dan Titik.

Membajak sawah atau "Megawe/ NggaruNgluku" dengan memakai hewan sapi merupa- 
kan atraksi tersendiri bagi wisatawan yang dapat diikuti ketika petani menyiapkan lahan untuk menanam padi atau polowijo.

Kelompok kandang "Ngudi Lestari" beranggotakan sekitar 32 orang dan banyaknya sapi sekitar 76 ekor. Ketua kelompok Suseno mengatakan pemberdayaan masyarakat adalah masyarakat berkreatif, didukung pemerintah dengan memberikan stimulan dana untuk menciptakan lapangan kerja bagi masyarakat. Selanjutnya beliau menyampaikan bahwa dengan kebersamaan, gotongroyong, ternyata kelompok ini dapat mengukir prestasi. Pada peringatan HUT RI tahun 2011 Kecamatan Mlati kelompok kandang "Ngudi Lestari" mendapat juara I kategori sapi indukan, dan juara II kebersihan lingkungan kandang.

\section{KESIMPULAN}

Berdasarkan rumusan masalah yang ditetapkan dan uraian dalam pembahasan di atas maka dapat disampaikan kesimpulan sebagai berikut:

1. Proses pemberdayaan masyarakat yang dilakukan oleh LPMD Ketingan adalah dengan membentuk organisasi desa wisata dan dilengkapi dengan Tim Pengelola Desa Wisata, dan membentuk kelompok-kelompok kecil seperti Kelompok Ternak Kandang Ngudi Lestari, Kelompok Simpan Pinjam Rukun Abadi, Kelompok Bakul Kecil Rumaket, Kelompok Usaha Bersama/ KUB Amanah dan kelompok lain, untuk meningkatkan dan mengembangkan kegiatan warga guna mencapai peningkatan kesejahteraan.

2. Upaya-upaya yang dilakukan dan penguatan kelembagaan dalam pemberdayaan masyarakat adalah melalui pengembangan potensi Desa Wisata Ketingan yang dilakukan dengan pembentukan paket wisata terpadu Model Manajemen Kluster, yang diprakarsai oleh Pascasarjana Prodi Magister Teknik Industri Universitas Islam Inonesia, dan melibatkan serta menggerakkan warga, UKM yang ada di 3 sentra yaitu sentra Desa Wisata Ketingan, sentra Desa Wisata Sendari dan sentra Mina Kepis Burikan, meningkatkan manfaat dan menarik minat wisatawan untuk berkunjung di Desa Wisata Ketingan.

Hasil dari pengembangan potensi yang ada di Desa Wisata Ketingan, maka Desa Wisata Ketingan mendapatkan penghargaan dan prestasi dari kegiatan lomba dan festifal yang diikuti oleh Desa Wisata Ketingan.

3. Desa Wisata Ketingan memiliki faktor pendukung yang menunjang dalam penampilan atraksi antara lain: papan Informasi dan peta wisata yang dapat memandu wisatawan, SDM yang banyak dan berkualitas, SDA yang indah dan subur, serta potensi Seni dan Budaya. Di samping ada faktor pendukung tetapi juga menghadapi hambatan dalam pelaksanaan kegiatannya antara lain: SDM, pendanaan dan kerukunan serta kepengurusan yang kurang maksimal.

\section{DAFTAR PUSTAKA}

Ahisma Putra. Heddy Shri dkk; 2000; Pengembangan Model Pariwisata Pedesaan Sebagai Alternatif Pembangunan Berkelanjutan; Laporan Penelitian Hibah Bersaing; Lembaga Penelitian UGM; Yogyakarta.

Bungin, Burhan 2003, Analisis Data Penelitian Kualitatif: Pemahaman Filosofis dan Metodologis ke Arah Penguasaan Model Aplikasi, Raja Grafindo Perkasa, Jakarta

Budi Handojo, 2008, Aspek Hukum Konservasi Sumberdaya Alam Hayati Melalui Pengembangan Ekowisata (Ecotourism), Studi di Desa Wisata Ketingan Tirtoadi Mlati Sleman, Yogyakarta. Magister 
Ilmu Hukum Fakultas Hukum Universitas Gajah Mada, Dokumen tidak dipublikasikan.

Chafid Fandeli, 1995, Pengembangan Ekowisata Berbasis Konservasi di Taman Nasional, Kerjasama Fak. Kehutanan UGM, Puspar UGM dan Kementerian Lingkungan Hidup Republik Indonesia, Jakarta.

Chafid Fandeli, Mukhlison, 2000, Pengusahaan Ekowisata, Fak. Kehutanan UGM dan Unit Konservasi Sumberdaya Alam DIY, Yogyakarta.

Damanik Janianton; 2005; Penanggulangan Kemiskinan Melalui Pariwisata; Kepel Press; Yogyakarta.

Dinas Pariwisata Kabupaten Sleman 2007 "Profil Desa Wisata Sleman"

Maryani, 2006, Pembangunan Pariwisata Bandung, Persepsi Wisatawan, Jurnal Pariwisata STIEPAR, volume 7, No.1 Februari 2006, Bandung PPPMSTIEPAR, YAPARIAKTRIPA

Moleong, Lexy J. 2005, Metodologi Penelitian Kualitatif, Remaja Rosdakarya, Bandung, edisi revisi
Pitana I.Gede dan Putu G Ayatri, 2005, Sosiologi Pariwisata, Penerbit Andi, Yogyakarta.

Rahman Faidlal, 2009, Pemberdayaan Masyarakat Melalui Pengembangan Desa Wisata; Program Studi Magister Kajian Pariwisata, Universitas Gajah Mada, Dokumen tidak dipublikasikan

Sastropoetro Santoso, 1988, Partisipasi, Komunikasi, Persuasi dan Disiplin Dalam Pembangunan Nasional, Alumni, Bandung

Singarimbun, Masri dan Sofian Effendi, 1983, Metode Penelitian Survai, LP3ES, Jakarta

Sedarmayanti; 2005, Membangun Kebudayaan dan Pariwista; Bunga Rampai tulisan Pariwisata, Mandar Maju, Bandung.

Wrihatnolo, Randy R. dan Riant Nugroho Dwidjowijoto, 2007, Manajemen Pemberdayaan: Sebuah Pengantar dan Panduan Untuk Pemberdayaan Masyarakat, PT Elex Media Komputindo, Kelompok Gramedia, Jakarta. 